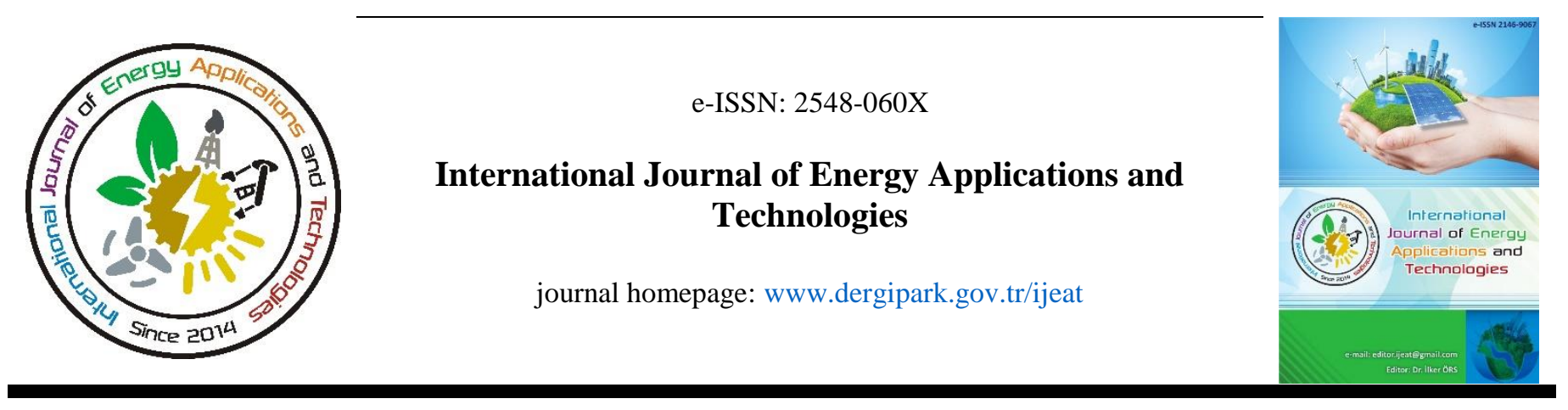

Original Research Article

\title{
Induction assisted pasteurization of honey
}

\author{
Tuncay Yılmaz ${ }^{*}$, Anıl Başaran ${ }^{2}$, Can Çivi $^{2}$ \\ ${ }^{1}$ Food Engineering Department, Manisa Celal Bayar University, Engineering Faculty, TURKEY \\ ${ }^{2}$ Mechanical Engineering Department, Manisa Celal Bayar University, Engineering Faculty, TURKEY
}

\author{
ARTICLE INFO \\ * Corresponding author \\ tuncay.yilmaz@cbu.edu.tr \\ Received October 4, 2018 \\ Accepted June 20, 2019 \\ Published by Editorial Board \\ Members of IJEAT \\ (C) This article is distributed by \\ Turk Journal Park System under \\ the CC 4.0 terms and conditions. \\ doi: $10.31593 /$ ijeat.467186
}

\begin{abstract}
Honey pasteurization is one of the important steps of honey processing which requires thermal energy to elevate temperature of the honey to inactivate enzymes and to inhibit bacteria. Common technique used for thermal treatment of honey is batch jacketed pasteurizer driven by electrical resistance to heat water, oil or steam. Each heating approach requires high amount of energy which is transferred directly or indirectly to the honey. Furthermore, heat generation is expensive and there are several steps which cause energy and exergy loses such as boiler, heater, pipe, heating medium, wall thickness of the vessel etc. Alternatively, induction is a technology using electromagnetic heating with unique advantages as heating metal surfaces directly and effectively. Inductive heating has been used for some industries as metallurgy, however, possible food applications such as batch pasteurization was not studied in detail. The objective of this research is comparing energy and exergy efficiencies of conventional jacketed vessel heater and inductive heater for honey pasteurization. Consequently, inductive method was found more beneficial compared to commercial method in terms of energy and exergy efficiency.
\end{abstract}

Keywords: honey pasteurization; induction assisted heating; energy efficiency

\section{Introduction}

As a definition in dictionary, honey is a sweet viscid material elaborated out of the nectar of flowers in the honey sac of various bees. It is a healthy product composing of $17-20 \%$ moisture, $80-85 \%$ carbohydrate and $0.5-1 \%$ proteins, amino acids, vitamins and minerals. Industry of honey is a complex process comprising sequential chain of processing such as initial extraction, dehumidification, liquefaction, heating, pasteurization, crystallization and packaging. Each step has unique impact on physicochemical and microbiological properties of the product. After harvesting, honey is centrifuged during the initial extraction step to eliminate impurities and waxes. Then honey is treated below $38^{\circ} \mathrm{C}$ for removing excess moisture to make it lower than $18 \%$. Heating is applied to control particle aggregation (pollen grains etc.), crystallization and viscosity, but it may lead some changes as increase in the amount complex sugars, augment of total acidity, partial activation of enzymes and increase in hydroxymethylurfural (HMF) therefore it is suggested that maximum heating should not exceed $40^{\circ} \mathrm{C}$. On the other hand, in terms of pasteurization, applied thermal treatment to honey is $72^{\circ} \mathrm{C}$ at $120 \mathrm{~s}$. Traditionally, hot water circulated jacketed vessels are used with central stirrer to make this step fast and effective. Unlike common usage of pasteurization in food industry as controlling microbiological quality, pasteurization is applied to honey to control structure of honey for commercial needs. By the way, honey can keep its typical liquid state on shelves. Other important step for commercial honey is crystallization, in which glucose monohydrate crystals can be formed as desired shape and size [1-2].

Pasteurization is a thermal treatment which is carried out on almost all food products for food safety purposes, including 
also prolonged shelf-life, requires special equipment as heat exchanger, which requires high number of consumables as electricity, hot water, hot oil, steam etc.[1, 3-4]. It is noted that one of the major expenditures of the companies is utilities used for thermal treatments. Therefore, convenient, cheap and energy efficient heating systems will be helpful for industry. For this view, electromagnetic induction can be suggested to overcome the need which can heat conductive materials directly [5]. Induction heating has two main mechanisms as Joule heating and magnetic hysteresis. By means of given heating mechanisms it does not require any intermediate systems to conduct heat to the material [6-7]. This heating method is used for metallurgy industry to heat metals to high degrees effectively. It is promising to adapt this approach to food industry to eliminate heating utilities [8-9]. In previous researches Başaran et al compared effectiveness of inductive and electrical boiler heater during continuous pasteurization of tomato paste and it is reported that induction is more effective than electrical boiler in terms of energy and exergy analysis [10]. On the other hand, there is some limited applications of induction in food are available such as inductive oven, however there is no commercial food process systems were observed in spite of some patents relate $\mathrm{d}$ to cooking, sterilization and water heater [11-13].

In this study pasteurization of honey is studied as a model system for batch pasteurization. Selected heat exchanger is jacketed vessel to make better adaptation of both systems for the same volume of the product with the same level of required total energy.

\section{System Description}

Honey pasteurization is a step after heating honey to $40^{\circ} \mathrm{C}$. During pasteurization honey is heated to $72^{\circ} \mathrm{C}$ for $120 \mathrm{~s}$. Conventional heating system is jacketed vessel with stirrer inside it for homogenous heating (Fig 1). Dimensions of the vessel are $1 \mathrm{~m}$ high and $1 \mathrm{~m}$ in diameter. There is water inside the jacked heated by electrical heater from $25^{\circ} \mathrm{C}$ to $90^{\circ} \mathrm{C}$. After achieving desired temperature for heating water vessel is filled with honey at $40^{\circ} \mathrm{C}$, it is heated to $72^{\circ} \mathrm{C}$ and maintained the temperature for $120 \mathrm{~s}$. The capacity of the vessel is $500 \mathrm{~L}$ and the volume of the heating water is $157 \mathrm{~L}$. The process conditions and properties of both product (honey) and working fluid (water) are given in Table 1. It is worth note here that there is no working fluid (side stream) required in the induction coil wrapped vessel. However, product properties are identical for both jacketed and induction coil wrapped vessels.

\section{Governing Equations}

The mass, energy, entropy and exergy balance equations for a control volume were employed to analyze the system thermodynamically. These balance equations with consideration of batch process were applied to find the heat and work input, the rate of exergy destruction (or irreversibility), the exergy changes, and the energy and exergy efficiencies [14].

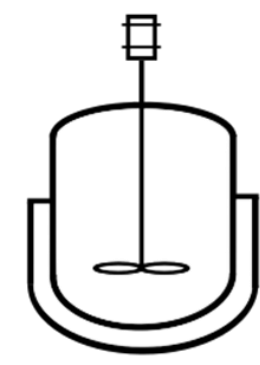

(a)

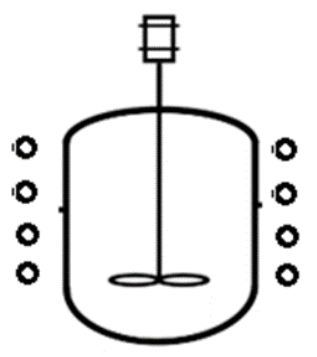

(b)

Fig. 1. a) jacketed vessel, b) induction coil wrapped vessel

Table 1. Operating conditions and the properties of product and working fluid at operating conditions

\begin{tabular}{lcc}
\hline & $\begin{array}{c}\text { Honey } \\
\text { (Product) }\end{array}$ & $\begin{array}{c}\text { Water } \\
\text { (Working Fluid) }\end{array}$ \\
\hline Initial Temperature $\left({ }^{\circ} \mathrm{C}\right)$ & 40 & 90 \\
Final Temperature $\left({ }^{\circ} \mathrm{C}\right)$ & 72 & 25 \\
Process Pressure $(\mathrm{kPa})$ & 101.25 & 101.25 \\
Volume $(\mathrm{L})$ & 500 & 157 \\
Mass $(\mathrm{kg})$ & 725 & 156.54 \\
Density $\left(\mathrm{kg} / \mathrm{m}^{3}\right)$ & 1450.00 & 997.05 \\
Specific heat $(\mathrm{kJ} / \mathrm{kgK})$ & 1.407 & 4.188 \\
\hline
\end{tabular}

The mass balance equation basically can be expressed as equality of mass at inlet and outlet. In general, it can be written in the rate form as;

$$
\sum m_{\text {in }}-\sum m_{\text {out }}=\Delta m_{C V}
$$

For the closed system without mass input and output $\Delta m_{C V}$ becomes zero and hence:

$$
\sum m_{\text {in }}=\sum m_{\text {out }}=m
$$

where $m$ is the mass, the subscripts in, out and CV stand for inlet, outlet and control volume, respectively.

The general energy balance for a closed system can be written as; 


$$
\begin{gathered}
E_{\text {in }}-E_{\text {out }}+E_{\text {gen }}=\Delta E_{C V} \\
Q_{C V}-W_{C V}=\sum m_{\text {in }}\left(u_{\text {in }}+\frac{V_{\text {in }}^{2}}{2}+g z_{\text {in }}\right)-\sum m_{\text {out }}\left(u_{\text {out }}+\right. \\
\left.\frac{V_{\text {out }}^{2}}{2}+g z_{\text {out }}\right)
\end{gathered}
$$

where $Q$ and $W$ are the net heat and work input/output, and $u$, $V, Z$ are the internal energy, velocity and elevation, respectively. Also, the subscripts "gen" stands for generation in the control volume.

The energy balance with negligible kinetic and potential energy as well as mass changes can be expressed by;

$$
Q-W=m \Delta u
$$

The energy efficiency of the system can be defined as the ratio of total energy output to total energy input.

$$
\eta_{\text {system }}=\frac{E_{\text {output }}}{E_{\text {input }}}=1-\frac{E_{\text {loss }}}{E_{\text {input }}}
$$

where in most cases "output" refers to "useful" one.

Entropy balance equation for a control volume can be expressed as;

$$
\sum m_{\text {in }} s_{\text {in }}-\sum m_{\text {out }} s_{\text {out }}=S_{\text {gen }}+\sum \frac{Q_{b}}{T_{b}}
$$

where $Q_{b}$ is heat transfer rate at boundary with temperature $T_{b}$. The terms $\sum \frac{Q_{b}}{T_{b}}$ is the time rate of entropy transfer through the portion of the boundary by heat transfer across boundary.

In this context, the specific exergy with neglecting kinetic and potential exergies can be defined as for a closed system;

$$
\psi=\left(u-u_{0}\right)-T_{0}\left(s-s_{0}\right)
$$

Multiplying specific exergy by the mass of the fluids gives total exergy;

$$
\begin{aligned}
& E x=m \psi \\
& E x=m\left(u-u_{0}\right)-T_{0}\left(s-s_{0}\right)
\end{aligned}
$$

where subscript " 0 " stands for the restricted dead state. $T_{0}$ is the dead state temperature, $u_{0}$ and $s_{0}$ are internal energy and entropy at the restricted dead state of $P_{0}$ and $T_{0}$

The general exergy rate balance may be expressed as follows;

$$
E x_{\text {dest }}=E x_{\text {heat }}-E x_{\text {work }}+E x_{\text {mass }, \text { in }}-E x_{\text {mass }, \text { out }}
$$

Exergy destruction (or irreversibility) can be defined as following equation. In this equation, firstly, the entropy generation $S_{g e n}$ is calculated and used in the equation;

$$
I=E x_{\text {dest }}=T_{0} S_{\text {gen }}
$$

Generally, the exergy efficiency (also called second law and exergetic efficiency) maybe expressed as the ratio of total exergy output to total exergy input.

$$
\varepsilon=\frac{E x_{\text {output }}}{E x_{\text {input }}}=1-\frac{E x_{\text {dest }}}{E x_{\text {input }}}
$$

\section{Results and Discussion}

In this study, energetic and exergetic performance of jacketed vessel and induction coil wrapped vessel pasteurizer were compared for honey pasteurization. The energy consumption of mixer is ignored in this study due to the fact that it is identical in the both compared systems and its energy consumption is relatively small compared to the total energy consumption of the analyzed systems. For each case required heat for honey kept constant and system was assumed as adiabatic. Therefore, all transfer equations solved under the same input conditions.

The following assumptions were considered for calculations used to evaluate each system;

- The friction losses in systems are neglected

- The kinetic and potential energy changes are neglected

- The kinetic, potential and chemical exergies are neglected

- Energy consumption of the mixer is ignored

- There is no heat transfer from the system to environment, system is adiabatic

- Honey is assumed as an incompressible

For each case, $500 \mathrm{~L}$ of honey were heated from $40^{\circ} \mathrm{C}$ to $72^{\circ} \mathrm{C}$ and temperature was maintained for $120 \mathrm{~s}$. Thermophysical properties of the honey is given in Table 2. Required heat for this situation is calculated as $32642.4 \mathrm{~kJ}$. As stated earlier, this required heat is indirectly supplied by high-temperature water (working fluid) in electric heater pasteurizer (jacketed pasteurizer) whereas it is directly ensured by induction current in inductive pasteurizer. Thermophysical properties of the water at process condition are indicated in Table 3 . It is worth note here that exergy of the water at final is equal to zero because water is in dead-state condition at final state. To obtained desired value it is observed that electrical heating requires higher amount of power compared to induction (Fig 2). This case shows that energy efficiency is high in induction.

Fig 3 represents exergy input and exergy output of the systems. Electrical heater shows extremely high exergy destruction compared to induction. While exergy input is $5845.06 \mathrm{~kJ}$ for induction it is $75614.98 \mathrm{~kJ}$ for electrical heater and outputs are $3052.39 \mathrm{~kJ}$ and $7139.75 \mathrm{~kJ}$ respectively. It means only $9.49 \%$ of exergy is covered at electrical heater while this value is $52.22 \%$ for induction. Exergy loses is related to irreversibility of the systems. Consequently, it is possible to say that entropy generation and therefore irreversibility is low at induction [15]. 
Table 2. Thermophysical properties of the honey at process states.

\begin{tabular}{lcccc}
\hline $\begin{array}{l}\text { Process } \\
\text { states }\end{array}$ & $\begin{array}{c}\text { Temperature, } \\
\mathbf{T}\left({ }^{\circ} \mathbf{C}\right)\end{array}$ & $\begin{array}{c}\text { Internal } \\
\text { Energy, } \\
\mathbf{u}(\mathbf{k j} / \mathbf{k g})\end{array}$ & $\begin{array}{c}\text { Entropy, } \\
\mathbf{s} \\
(\mathbf{k j} / \mathbf{k g K})\end{array}$ & $\begin{array}{c}\text { Exergy, } \\
\mathbf{E x}(\mathbf{k J})\end{array}$ \\
\hline Initial & 40 & 440.6 & 8.0856 & 372.64 \\
Final & 72 & 485.63 & 8.2225 & 3425.03 \\
\hline
\end{tabular}

Table 3. Thermophysical properties of the water at process states.

\begin{tabular}{lcccc}
\hline $\begin{array}{l}\text { Process } \\
\text { states }\end{array}$ & $\begin{array}{c}\text { Temperature, } \\
\mathbf{T}\left({ }^{\mathbf{o}} \mathbf{C}\right)\end{array}$ & $\begin{array}{c}\text { Internal } \\
\text { Energy, } \\
\mathbf{u}(\mathbf{k j} / \mathbf{k g})\end{array}$ & $\begin{array}{c}\text { Entropy, } \\
\mathbf{s} \\
(\mathbf{k j} / \mathbf{k g K})\end{array}$ & $\begin{array}{c}\text { Exergy, } \\
\mathbf{E x}(\mathbf{k J})\end{array}$ \\
\hline Initial & 90 & 377.06 & 1.1928 & 4087.37 \\
Final & 25 & 104.92 & 0.3672 & 0 \\
\hline
\end{tabular}

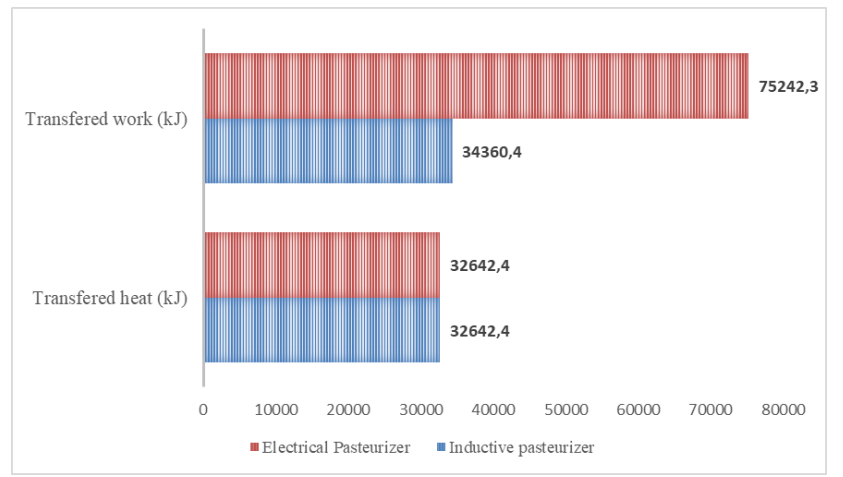

Fig. 2 Power and heat input of each pasteurization systems
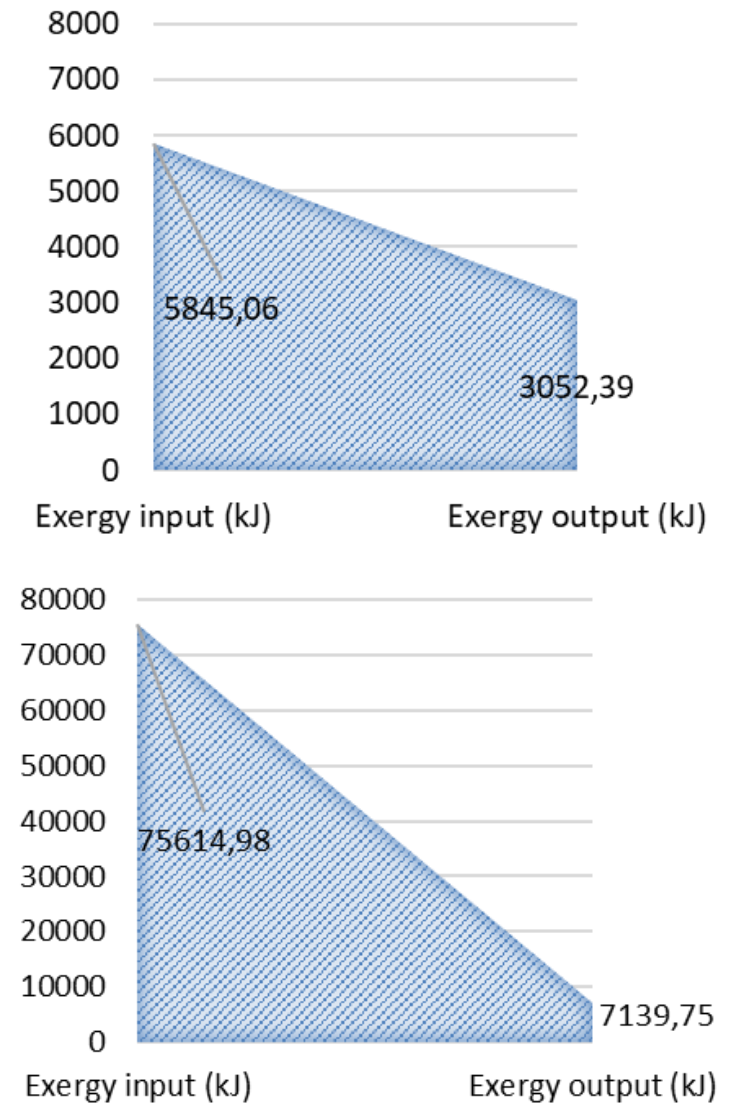

Fig. 3 Exergy values of the systems Inductive pasteurizer on the top and electrical pasteurizer on the below
In previous studies Başaran et al. [10] reported that inductive heating system has $95.00 \%$ energy efficiency and $46.56 \%$ second law efficiency while the conventional heating system with electric-boiler has $75.43 \%$ energy efficiency and $16.63 \%$ exergy efficiency. As a consequence, inductive method was found more beneficial compared to commercial method having higher energy and exergy efficiency for continuous pasteurization of tomato paste. For the continuous pasteurization of milk Başaran et al showed that the pasteurization system with electric-boiler has $67.56 \%$ energy efficiency and $3.57 \%$ exergy efficiency. Induction-heater pasteurization system has best energetic and exergetic performance than electric-boiler system for the milk pasteurization as well [16].

Main reasons of great variation between two systems in terms of energy and exergy efficiency can be explained by number of indirect heating steps during electrical heater as steps such as water heating and heat transfer from water to the vessel. However, vessel wall which is a metal can be heated directly by means of induction and it has observable benefits at honey pasteurization system by lowering energy and exergy losses.

\section{Conclusion}

Honey pasteurization is one of the most important steps for product quality and this step requires high amount of energy as well. In this study alternative heating method was compared theoretically in terms of energy and exergy efficiencies. For pasteurizing the $500 \mathrm{~L}$ of honey required $32642.4 \mathrm{~kJ}$ heat energy and for obtaining this value while jacketed vessel requires $75242.3 \mathrm{~kJ}$ work, induction needs almost same amount of energy that has to heat honey which is $34360.4 \mathrm{~kJ}$. For the second law efficiency it was found that exergy input for electrical heating is $75614.98 \mathrm{~kJ}$ and output is $7139.75 \mathrm{~kJ}$ which means there is only $9.49 \%$ efficiency. However, for induction, to obtain $3052.39 \mathrm{~kJ}$ exergy output there is $\mathbf{5 8 4 5 . 0 6}$ exergy input was calculated. It means that exergy destruction is dramatically low at induction system. It can be explained by direct heating of the system eliminating auxiliary heat transfer steps happens during electrical heating.

This study shows that inductive heating is promising approach for batch pasteurization systems, and it can be applied to some food systems such as honey processing.

\section{References}

[1] Heldman, Dennis R., Daryl B. Lund, and Christina Sabliov, E., 2006, Handbook of Food Engineering; CRC Press.

[2] Baglio, E., 2018, Chemistry and Technology of Honey Production. 
[3] Singh, R. P.,Heldman, D. R., 2001, Introduction to Food Engineering 5th Edition; Gulf Professional Publishing.

[4] Shah RK, S. D., 2012, Fundamentals of Heat Exchanger Design; JOHN WILEY \& SONS, INC.

[5] Rudnev, V. I., Loveless, D., Cook, R., \& Black, M., 2002, Handbook of Induction Heating (Manufacturing Engineering and Materials Processing); Marcel Dekker Inc: New York.

[6] Zinn, S., Semiatin, S. L., 1988, Elements of Induction Heating Design, Control and Aplications; ASM International.

[7] Vairamohan, B.,Bran, I.,Bellefon, G. M. De., 2011, "What' S New in Electrotechnologies for Industrial Process Heating ?". 156-164.

[8] El-Mashad, H. M.,Pan, Z., 2017, "Application of Induction Heating in Food Processing and Cooking". Food Engineering Reviews 9 (2), 82-90.

[9] GERMAN, R. M., 1996, Sintering Theory and Practice.; Solar-Terrestrial Physics.

[10] Başaran, A., Yılmaz, T.,Çivi, C., 2018, "Application of Inductive Forced Heating as a New Approach to Food Industry Heat Exchangers: A Case studyTomato Paste Pasteurization". Journal of Thermal Analysis and Calorimetry.

[11] Umali Ignacio R, Jr. Elmido Dennis U, E. L. U., "Multipurpose Induction Cooking Utensil. International Patent. No: Ph12015000089 (A1)2016-10-03.".

[12] M., R., "Induction Holding, Warming, and Cooking System Having in-Unit Magnetic Control. International Patent. No: Wo2017044150 (A1)2017-03-16.".

[13] PC., H., 2017, "Mixer Capable of High Frequency Induction Heating. International Patent. No: Wo2017043875 (A1)—2017-03-16.".

[14] Kanoglu, M.,Dincer, I.,Rosen, M. A., 2007 , "Understanding Energy and Exergy Efficiencies for Improved Energy Management in Power Plants". Energy Policy 35 (7), 3967-3978.

[15] Akar, S.,Rashidi, S.,Esfahani, J. A., 2017, "Second Law of Thermodynamic Analysis for Nanofluid Turbulent Flow around a Rotating Cylinder". Journal of Thermal Analysis and Calorimetry 132 (2), 1189-1200.

[16] Başaran, A.,Yılmaz, T.,Çivi, C., "Comparison of Conventional and Inductive Driven Milk Pasteurization Systems According to Energy and Exergy". In 2.International Conference on Material Science and Technology in Cappadocia (IMSTEC 2017); pp 256-260. 